\title{
Relation between oral contraceptive hormones and blood clotting
}

\author{
L. POLLER \\ From Withington Hospital, West Didsbury Hospital, Manchester
}

SYNOPSIS Oral contraception with conventional oestrogen/progestogen preparations produces raised levels of clotting factors and increased platelet aggregation. Although these changes do not involve as broad a spectrum of clotting factors as thrombosis and the third trimester of pregnancy, they do not appear a desirable side effect and may be responsible for the increased risk of thrombosis. Oral contraception with progestogen alone does not appear to cause similar clotting and platelet changes.

When oral contraceptive hormones became generally available in Britain workers in this laboratory became interested in the possibility that these hormones might produce a thrombotic tendency. To some extent they simulate pregnancy, which is accompanied by a rise in certain clotting factors and an acknowledged increased incidence of thromboembolism. Impetus was given to our work by reports in the literature of thromboembolism in Britain in women taking oral contraceptives (Jordan, 1961; Zilkha, 1964). Investigations were therefore performed to ascertain whether abnormal clotting tests resulted from taking the oral contraceptive hormones, although we had great difficulty at first in getting adequate numbers of subjects for statistical appraisal. The study was also influenced by a report on five women followed for one cycle of oral contraception by Egeberg and Owren (1963) who found an accelerated ' $p$ \& p' test and raised factor VIII leve's.

\section{First Trial}

The first trial was controlled by three parallel groups. The first was of normal women not taking oral contraceptives and the second of normal women before and after they undertook strenuous physical exercise, known to cause raised levels of factor VIII (Rizza, 1961). Factor
VII levels and heparin plasma clotting times were also related to a parallel group of women who had experienced recent thrombotic episodes. Already it had been seen that patients in this group tend to have raised factor VII activity and a shortened heparin clotting time (Poller, 1957).

The following tests were performed on a group of women taking combined cestrogenprogestogen preparations, and on parallel controls: prothrombin activity, cephalin time, heparin plasma clotting time, factor VII assay, and factor VIII assay. Results are reported directly as clotting times to avoid artefacts arising from the use of percentages from dilution curves. Where a percentage is used, the percentage rise in clotting activity was calculated from the formula:

$\frac{\text { clotting time control subject }(\mathrm{sec})}{\text { clotting time 'pill' subject }(\mathrm{sec})} \times 100$.

This tends to underestimate the rise when compared with percentages obtained from dilution curves. For analysis, each group was compared with its parallel control groups and results were calculated as significant at the $5 \%$ level. No account was taken of the fact that the studies were serial ones on the same subjects: they were analysed as separate populations in order to be conservative in accepting significant changes.

The results in the oral contraceptive group 


\begin{tabular}{|c|c|c|c|c|c|c|c|c|c|c|c|c|c|}
\hline & \multirow{3}{*}{$\begin{array}{l}\text { Prothrombin } \\
\text { Activity (\%) }\end{array}$} & \multirow{2}{*}{\multicolumn{2}{|c|}{$\begin{array}{l}\text { Factor VII } \\
\text { Assay } 20 \% \\
\text { Dilution (sec) }\end{array}$}} & \multirow{2}{*}{\multicolumn{2}{|c|}{$\begin{array}{l}\text { Cephalin Time } \\
\text { (sec) }\end{array}$}} & \multirow{2}{*}{\multicolumn{2}{|c|}{$\begin{array}{l}\text { Heparin } \\
\text { Plasma Clotting } \\
\text { Time (min) }\end{array}$}} & \multicolumn{6}{|c|}{ Factor VIII Assay (sec) } \\
\hline & & & & & & & & $10 \%$ & & $20 \%$ & & $30 \%$ & \\
\hline & & Mean & $S D$ & Mean & $S D$ & Mean & $S D$ & Mean & $S D$ & Mean & $S D$ & Mean & $S D$ \\
\hline $\begin{array}{l}\text { Treated group } \\
\text { Control group }\end{array}$ & $\begin{array}{l}100 \\
100\end{array}$ & $\begin{array}{l}18 \cdot 5 \\
18 \cdot 9\end{array}$ & $\begin{array}{l}5 \cdot 5 \\
4 \cdot 4\end{array}$ & $\begin{array}{l}62 \cdot 7 \\
63 \cdot 4\end{array}$ & $\begin{array}{l}5 \cdot 3 \\
4 \cdot 7\end{array}$ & $\begin{array}{l}7 \cdot 1 \\
6 \cdot 9\end{array}$ & $\begin{array}{l}2 \cdot 6 \\
2 \cdot 0\end{array}$ & $\begin{array}{l}18 \cdot 1 \\
18 \cdot 5\end{array}$ & $\begin{array}{l}3 \cdot 1 \\
2 \cdot 7\end{array}$ & $\begin{array}{l}15 \cdot 0 \\
15 \cdot 0\end{array}$ & $\begin{array}{l}2 \cdot 4 \\
1 \cdot 8\end{array}$ & $\begin{array}{l}14 \cdot 6 \\
14 \cdot 5\end{array}$ & $\begin{array}{l}1 \cdot 6 \\
0 \cdot 3\end{array}$ \\
\hline
\end{tabular}

Table I Results in women on oral contraceptives and normal female controls

(Table I) were at first sight negative. There was no significant difference between them as a group and the normal subjects, although significantly raised activity in factor VII and factor VIII was found in the thrombotic and exercise groups respectively (Tables II and III). However, when the results were reanalysed on a time basis (Thomson and Poller, 1965), a significant rise in factor VII activity was found from the third month onwards (Table IV). The other clotting parameters were not significantly different from normal.

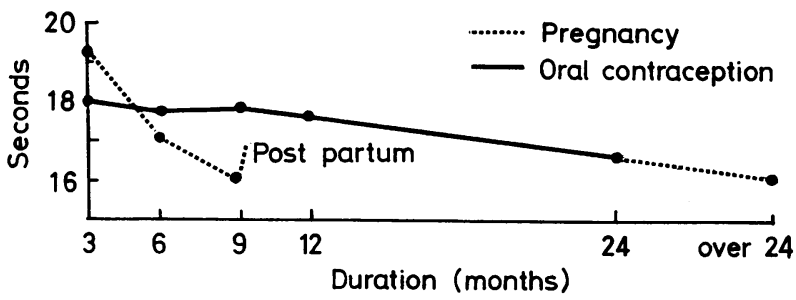

Fig. 1 Clotting times for factor VII assays during pregnancy contrasted with similar periods of oral contraception.

\section{Second Trial}

In view of these findings, the emphasis was on factor VII in the second study. Larger $\stackrel{\widetilde{\Phi}}{\Phi}$ numbers of women volunteered and also womeng who had been taking the preparations longer. To see whether the raised activity in factor VII ${ }^{\circ}$ levels showed any tendency to be cumulative the $\vec{\omega}$ 'pill' group was compared with women in theo three trimesters of pregnancy and a postpartum group as well as the parallel normal group. Thisis study showed that the rise in factor VII activity $\overrightarrow{\dot{\omega}}$ was indeed significant from the third month and was also cumulative. The level reached that of the third trimester of pregnancy after two years of oral contraception (Fig. 1 and Tables V, VI, and ${ }_{-}$ VII).

Factor $\mathrm{X}$ levels were also studied in this later investigation because of the work by Hougie, Rutherford, Banks, and Coburn in Seattle (1965). They reported a rise in factor $X$ in women taking $\vec{e}$ Ortho-Novin, although this was not reported on: a time basis. We were able to confirm their findings in a larger number of patients using a variety? of different preparations and relate our findings to the duration of the courses for each prepara-

\begin{tabular}{|c|c|c|c|c|c|c|c|}
\hline & \multicolumn{2}{|c|}{$\begin{array}{l}\text { Cephalin Time } \\
\text { (sec) }\end{array}$} & \multicolumn{2}{|c|}{$\begin{array}{l}\text { Factor VII } \\
\text { Assay } 20 \% \\
\text { Dilution (sec) }\end{array}$} & \multicolumn{2}{|c|}{$\begin{array}{l}\text { Heparin Plasma } \\
\text { Clotting Time } \\
\text { (min) }\end{array}$} & $\begin{array}{l}a \frac{0}{3} \\
\frac{2}{\rightleftarrows}\end{array}$ \\
\hline & Mean & $S D$ & Mean & $S D$ & Mean & $S D$ & \\
\hline $\begin{array}{l}\text { Patients } \\
\text { Controls }\end{array}$ & $\begin{array}{l}59 \cdot 7 \\
61 \cdot 5\end{array}$ & $\begin{array}{r}10.0 \\
5.0\end{array}$ & $\begin{array}{l}17 \cdot 4 \\
19 \cdot 4\end{array}$ & $\begin{array}{l}1.94 \\
1 \cdot 5\end{array}$ & $\begin{array}{l}4 \cdot 0 \\
7 \cdot 7\end{array}$ & $\begin{array}{l}1 \cdot 1 \\
2 \cdot 2\end{array}$ & $\dot{\sigma}$ \\
\hline
\end{tabular}

Table II Results in patients with deep vein thrombosis and parallel controls

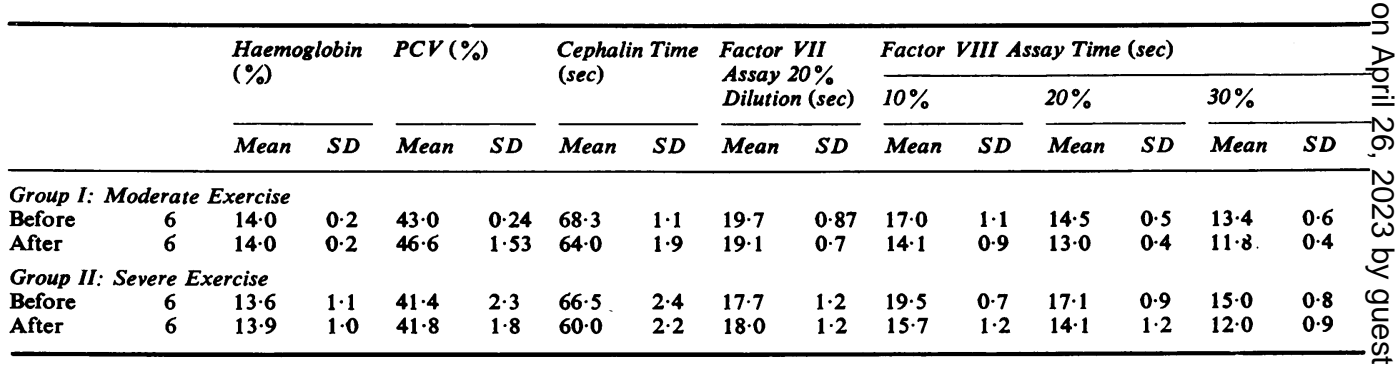

Table III Results in women before and after exercise

\begin{tabular}{|c|c|c|c|c|c|c|c|c|c|c|c|}
\hline \multirow{2}{*}{\multicolumn{2}{|c|}{ Before Treatment }} & \multicolumn{10}{|c|}{ Months after Treatment } \\
\hline & & \multicolumn{2}{|l|}{ One } & \multicolumn{2}{|l|}{ Two } & \multicolumn{2}{|l|}{ Three } & \multicolumn{2}{|c|}{ Three to Six } & \multicolumn{2}{|c|}{ Six to 12} \\
\hline Mean (sec) & $S D$ & Mean & $S D$ & Mean & $S D$ & Mean & $S D$ & Mean & $S D$ & Mean & $S D$ \\
\hline $20 \cdot 1$ & $2 \cdot 23$ & $18 \cdot 9$ & $1 \cdot 78$ & $19 \cdot 8$ & 1.4 & $18 \cdot 4$ & $1 \cdot 58$ & $18 \cdot 5$ & $2 \cdot 2$ & $17 \cdot 8$ & $1 \cdot 34$ \\
\hline
\end{tabular}

Table IV Factor VII assays during course of therapy 


\begin{tabular}{|c|c|c|c|c|c|}
\hline \multicolumn{3}{|c|}{ Duration of Course and Test } & Total & $\begin{array}{l}\text { Mean Time } \\
(\mathrm{sec})\end{array}$ & $S D$ \\
\hline Antenatal Gr & $\begin{array}{l}\text { Cephalin } \\
\text { VIII assay } \\
\text { Factor } \mathrm{X} \text { assay }\end{array}$ & $\left\{\begin{array}{l}10 \% \\
20 \% \\
30 \%\end{array}\right.$ & $\begin{array}{l}13 \\
13 \\
13 \\
13 \\
13 \\
13 \\
12\end{array}$ & $\begin{array}{l}19 \cdot 4 \\
64 \cdot 5 \\
17 \cdot 3 \\
14 \cdot 6 \\
13 \cdot 1 \\
18 \cdot 6\end{array}$ & $\begin{array}{l}2 \cdot 27 \\
2 \cdot 94 \\
2 \cdot 79 \\
2 \cdot 02 \\
1 \cdot 43 \\
0 \cdot 30\end{array}$ \\
\hline 13-24 weeks & $\begin{array}{l}\text { Factor VII assay } \\
\text { Cephalin } \\
\text { VIII assay } \\
\text { Factor X assay }\end{array}$ & $\left\{\begin{array}{l}10 \% \\
20 \% \\
30 \%\end{array}\right.$ & $\begin{array}{l}26 \\
26 \\
24 \\
24 \\
24 \\
16\end{array}$ & $\begin{array}{l}17 \cdot 2 \\
63 \cdot 4 \\
17 \cdot 9 \\
15 \cdot 0 \\
13 \cdot 6 \\
17 \cdot 7\end{array}$ & $\begin{array}{l}0.96 \\
3 \cdot 72 \\
3.01 \\
1 \cdot 7 \\
1.07 \\
1.04\end{array}$ \\
\hline 25-36 weeks & $\begin{array}{l}\text { Factor VII assay } \\
\text { Cephalin } \\
\text { VIII assay } \\
\text { Factor X assay }\end{array}$ & $\left\{\begin{array}{l}10 \% \\
20 \% \\
30 \%\end{array}\right.$ & $\begin{array}{l}37 \\
37 \\
27 \\
27 \\
27 \\
15\end{array}$ & $\begin{array}{l}16 \cdot 2 \\
61 \cdot 6 \\
14 \cdot 5 \\
13 \cdot 1 \\
12 \cdot 3 \\
15 \cdot 6\end{array}$ & $\begin{array}{l}0 \cdot 78 \\
2 \cdot 53 \\
1 \cdot 28 \\
1 \cdot 15 \\
0.93 \\
0 \cdot 87\end{array}$ \\
\hline Postpartum & $\begin{array}{l}\text { Factor VII assay } \\
\text { Cephalin } \\
\text { Factor X assay }\end{array}$ & & $\begin{array}{l}26 \\
21 \\
27\end{array}$ & $\begin{array}{l}16.7 \\
59.5 \\
16.9\end{array}$ & $\begin{array}{l}1.23 \\
1.66 \\
1.31\end{array}$ \\
\hline
\end{tabular}

Table $\mathrm{V}$ Results in pregnant and postpartum groups

\begin{tabular}{|c|c|c|c|c|c|c|}
\hline & \multicolumn{3}{|c|}{ Normal Controls } & \multicolumn{3}{|c|}{ Women on Oral Contraceptives } \\
\hline & Total & $\begin{array}{l}\text { Mean Time } \\
(\mathrm{sec})\end{array}$ & $S D$ & Total & $\begin{array}{l}\text { Mean Time } \\
(\mathrm{sec})\end{array}$ & $S D$ \\
\hline $\begin{array}{l}\text { Factor VII assay } \\
\text { Cephalin }\end{array}$ & $\begin{array}{l}112 \\
122\end{array}$ & $\begin{array}{l}18 \cdot 8 \\
65 \cdot 2\end{array}$ & $\begin{array}{l}1.54 \\
1.48\end{array}$ & $\begin{array}{l}170 \\
196\end{array}$ & $\begin{array}{l}18 \cdot 0 \\
64 \cdot 1\end{array}$ & $\begin{array}{l}1.91 \\
1.98\end{array}$ \\
\hline $10 \%$ & 53 & $18 \cdot 2$ & 1.31 & 60 & $18 \cdot 1$ & $3 \cdot 2$ \\
\hline Factor & 53 & $15 \cdot 1$ & $1 \cdot 12$ & 60 & $15 \cdot 0$ & $2 \cdot 5$ \\
\hline $30 \%$ & 53 & $14 \cdot 3$ & $1 \cdot 37$ & 60 & $14 \cdot 6$ & $1 \cdot 6$ \\
\hline Factor $\mathrm{X}$ assay & 27 & $18 \cdot 5$ & $1 \cdot 11$ & 52 & $17 \cdot 4$ & $1 \cdot 12$ \\
\hline
\end{tabular}

Table VI Results in normal controls and in women on oral contraceptives

\begin{tabular}{|c|c|c|c|c|}
\hline \multicolumn{2}{|c|}{ Duration of Course and Test } & \multicolumn{3}{|c|}{ Total Mean Time $(\mathrm{sec}) S D$} \\
\hline 0 week & $\left\{\begin{array}{l}\text { Factor VII assay } \\
\text { Factor X assay } \\
\text { Cephalin }\end{array}\right.$ & $\begin{array}{r}23 \\
9 \\
23\end{array}$ & $\begin{array}{l}18 \cdot 9 \\
18 \cdot 8 \\
66 \cdot 0\end{array}$ & $\begin{array}{l}1 \cdot 77 \\
0.6 \\
1 \cdot 72\end{array}$ \\
\hline 1 month & $\left\{\begin{array}{l}\text { Factor VII assay } \\
\text { Cephalin }\end{array}\right.$ & $\begin{array}{l}15 \\
15\end{array}$ & $\begin{array}{l}18 \cdot 4 \\
64 \cdot 0\end{array}$ & $\begin{array}{l}1.5 \\
1.96\end{array}$ \\
\hline 2 months & $\left\{\begin{array}{l}\text { Factor VII assay } \\
\text { Cephalin }\end{array}\right.$ & $\begin{array}{l}13 \\
13\end{array}$ & $\begin{array}{l}18 \cdot 8 \\
63 \cdot 7\end{array}$ & $\begin{array}{l}1 \cdot 4 \\
1.92\end{array}$ \\
\hline 2 months & $\left\{\begin{array}{l}\text { Factor VII assay } \\
\text { Factor X assay (1-3 months) } \\
\text { Cephalin }\end{array}\right.$ & $\begin{array}{l}18 \\
18 \\
18\end{array}$ & $\begin{array}{l}18 \cdot 0 \\
18 \cdot 0 \\
64 \cdot 3\end{array}$ & $\begin{array}{l}1 \cdot 5 \\
2 \cdot 04 \\
2 \cdot 24\end{array}$ \\
\hline 4-6 months & $\left\{\begin{array}{l}\text { Factor VII assay } \\
\text { Cephalin }\end{array}\right.$ & $\begin{array}{l}35 \\
36\end{array}$ & $\begin{array}{l}17 \cdot 7 \\
63 \cdot 9\end{array}$ & $\begin{array}{l}2 \cdot 2 \\
1 \cdot 35\end{array}$ \\
\hline 7-12 months & $\left\{\begin{array}{l}\text { Factor VII assay } \\
\text { Factor X assay } \\
\text { Cephalin }\end{array}\right.$ & $\begin{array}{l}38 \\
10 \\
39\end{array}$ & $\begin{array}{l}17 \cdot 8 \\
17 \cdot 1 \\
65 \cdot 0\end{array}$ & $\begin{array}{l}1.46 \\
1 \cdot 18 \\
2 \cdot 0\end{array}$ \\
\hline 12 months & $\left\{\begin{array}{l}\text { Factor VII assay } \\
\text { Factor X assay } \\
\text { Cephalin }\end{array}\right.$ & $\begin{array}{r}9 \\
7 \\
14\end{array}$ & $\begin{array}{l}17 \cdot 1 \\
16 \cdot 9 \\
64 \cdot 4\end{array}$ & $\begin{array}{l}1.89 \\
0.41 \\
1.6\end{array}$ \\
\hline 2 years & $\left\{\begin{array}{l}\text { Factor VII assay } \\
\text { Factor X assay } \\
\text { Cephalin }\end{array}\right.$ & $\begin{array}{l}18 \\
15 \\
19\end{array}$ & $\begin{array}{l}16 \cdot 1 \\
17 \cdot 4 \\
65 \cdot 5\end{array}$ & $\begin{array}{l}1 \cdot 1 \\
1 \cdot 5 \\
1 \cdot 31\end{array}$ \\
\hline
\end{tabular}

Table VII Results in women on oral contraceptives according to duration of course

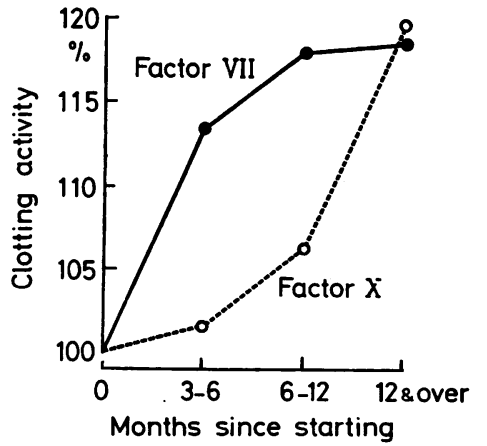

Fig. 2 Factor VII and X levels after sequential oral contraception.

tion. The activity of factor $\mathrm{X}$ was raised from the third month onwards, as was that of factor VII. Factor VIII levels again showed no change although they were significantly raised in the third trimester of pregnancy (Poller and Thomson, 1966).

\section{Study of Sequential Contraceptives}

Women on sequential preparations were studied to see whether the effect was similar to that of the conventional combined preparations. These results were not reported until some years later when the question of the risk of thrombosis with sequential preparations was being discussed (Poller and Thomson, 1969). The same pattern of rising levels in factors VII and X was seen (Fig. 2). The raised level of factor VII became significant at three months and showed a progressive increase subsequently: that of factor $X$ became significant from six months onwards. There was therefore no evidence that sequential preparations represented any advance in this respect.

\section{Current Investigations}

The first part of the investigations over the five years up to 1967 was made with extreme difficulty because women on oral contraceptives were unwilling to come to hospital for clotting tests even though free tablets, transport, and expenses were provided. The number of women taking the steroids was still comparatively small and there was a continual official denial of any risk of thrombosis. Thus there was little real motivation for such studies in lay circles. Our 
earlier work was therefore not as well planned as we should have liked, but nevertheless the findings from these studies on clotting appeared convincing.

In 1967 the problems of persuading women to attend for clotting studies were much simplified with the publication of the Medical Research Council's statistical findings of an increased incidence of thromboembolism in women taking oral contraceptives. As a result of this and of the publicity which ensued on the publication of our results, we were able to make public appeals for volunteers for subsequent trials which could be planned prospective investigations.

Investigations were first designed to determine whether the changes in coagulation depended on the dose of anti-ovulatory agent, and whether the time relationship of the consequent changes would be affected by the hormonal dose. Women volunteers were given two different preparations of relatively low hormonal content, one of which, Ortho-Novin, contained twice the dose (norethisterone $2 \mathrm{mg}$, mestranol $0.1 \mathrm{mg}$ ) of the other, Norinyl-1. Parallel studies were performed on controls and a group of patients in the third trimester of pregnancy. The results are set out in Tables VIII and IX.

The cephalin times, which measure the intrinsic clotting system, showed a significant shortening with the unmodified test and with the kaolinactivated test from the sixth month onwards.

The levels of factors VII and X were significantly increased in the combined group and in each of the three individual groups of patients on oral contraceptives from the third month on $\frac{\curvearrowright}{\overline{5}}$ wards. There was no significant differencet between the patients on Norinyl-1 and Ortho Novin when these were compared. The second group of patients taking Norinyl-1, that is, those who had already been taking other preparations? of oral contraceptive, showed significantly raise levels of factors VII and $X$ before starting Norinyl-1, and these levels persisted and con $\frac{0}{7}$ tinued to rise progressively during the study $\mathbb{Q}$ Table VIII gives the values for the individuat assays, and these show progressive shortening in the tests, ie, increase of activity, expressed as clotting times. Figure 3 illustrates the results for factors VII and X assays. The results at the nine month stage were still significantly lower thang those in the antenatal patients in the thirds trimester of pregnancy. The coagulation response $\vec{\omega}$ in the two groups appeared to be identical andthe same as the 'high-dose' groups. In otherg words, the changes do not appear to be a simpleos matter of dose-dependency (Poller, Tabiowo and Thomson, 1968). The answer to the problem did not appear therefore to lie in reducing the dosage of conventional preparations. Hormonew sufficient for oral contraception was apparently sufficient to produce the clotting changes.

The problem was approached in another waye by using a progestogen-only 'pill' preparation when this became available for clinical trial in 1968 (Poller, Priest, and Thomson, 1969a; Poller Thomson, Tabiowo, and Priest, 1969b). The्๊ reason for embarking on the trial with a prepara零

\begin{tabular}{|c|c|c|c|c|c|c|c|c|}
\hline & \multicolumn{2}{|c|}{ Cephalin Times (sec) } & \multicolumn{2}{|c|}{$\begin{array}{l}\text { Kaolin-activated } \\
\text { Cephalin Times }(\mathrm{sec})\end{array}$} & \multicolumn{2}{|c|}{ Factor VII $(\mathrm{sec})$} & \multicolumn{2}{|c|}{ Factor $X(\mathrm{sec})$} \\
\hline & Mean & $\begin{array}{l}\text { Standard } \\
\text { Deviation }\end{array}$ & Mean & $\begin{array}{l}\text { Standard } \\
\text { Deviation }\end{array}$ & Mean & $\begin{array}{l}\text { Standard } \\
\text { Deviation }\end{array}$ & Mean & $\begin{array}{l}\text { Standard } \\
\text { Deviation }\end{array}$ \\
\hline \multicolumn{9}{|l|}{ Norinyl-I } \\
\hline Before starting & $70 \cdot 8$ & $5 \cdot 64$ & $48 \cdot 2$ & $5 \cdot 34$ & $17 \cdot 8$ & $1 \cdot 758$ & $18 \cdot 5$ & 1.934 \\
\hline 2 months & $69 \cdot 8$ & 6.02 & $46 \cdot 2$ & $4 \cdot 35$ & $18 \cdot 0$ & 0.95 & $18 \cdot 0$ & 1.016 \\
\hline 3 months & $56 \cdot 2$ & $8 \cdot 19$ & $46 \cdot 2$ & $5 \cdot 12$ & $17 \cdot 1$ & $1 \cdot 38$ & $17 \cdot 4$ & $1 \cdot 184$ \\
\hline 6 months & $61 \cdot 5$ & $4 \cdot 35$ & $43 \cdot 3$ & $4 \cdot 75$ & $16 \cdot 8$ & $1 \cdot 28$ & $17 \cdot 1$ & $1 \cdot 334$ \\
\hline 9 months & $61 \cdot 1$ & $3 \cdot 12$ & $44 \cdot 1$ & 3.59 & $16 \cdot 3$ & $1 \cdot 385$ & $16 \cdot 7$ & $1 \cdot 337$ \\
\hline \multicolumn{9}{|l|}{ Ortho-Novin } \\
\hline Before starting & $69 \cdot 3$ & 5.95 & 46.9 & $4 \cdot 64$ & $17 \cdot 8$ & $1 \cdot 273$ & $18 \cdot 8$ & $1 \cdot 260$ \\
\hline 2 months & $66 \cdot 5$ & $6 \cdot 74$ & $44 \cdot 5$ & $4 \cdot 43$ & $18 \cdot 3$ & $1 \cdot 193$ & $17 \cdot 9$ & 1.04 \\
\hline 3 months & $60 \cdot 4$ & $3 \cdot 117$ & $42 \cdot 1$ & 3.48 & $17 \cdot 9$ & $1 \cdot 74$ & $18 \cdot 1$ & $1 \cdot 058$ \\
\hline 6 months & 58.6 & $2 \cdot 235$ & $41 \cdot 6$ & 2.66 & $17 \cdot 4$ & $1 \cdot 375$ & $16 \cdot 2$ & 1.70 \\
\hline 9 months & $58 \cdot 7$ & 3.46 & $41 \cdot 4$ & 1.73 & $17 \cdot 3$ & 1.421 & $16 \cdot 3$ & $1 \cdot 33$ \\
\hline
\end{tabular}

Table VIII Results in patients using oral contraceptive for the first time

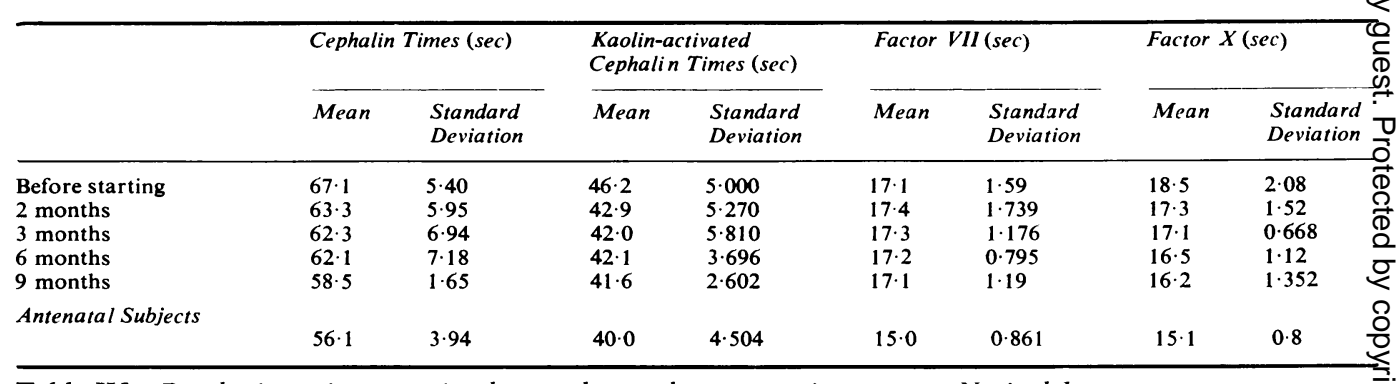

Table IX Results in patients previously on other oral contraceptives now on Norinyl-1 


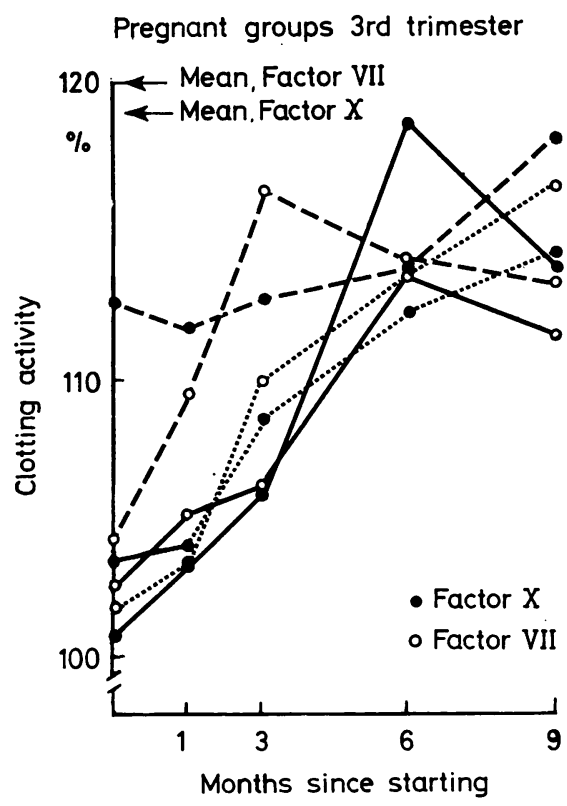

Fig. 3 Factor VII and X levels: rise in clotting activity with low dose preparations.

Ortho-Novin group.

- - - - Norinyl-1 group using pill for first time.

_ _ - Norinyl-1 group previously on other pill preparations.

tion free from oestrogen was based on the knowledge that oestrogens may have a beneficial effect on haemostasis when used clinically. Whether this is due to an effect on blood coagulation, platelets, or ground substance is not clear (Ulutin, 1969). Oestrogens have been used clinically to promote haemostasis (Blackburn, 1963; Berkarda, Akokan, and Derman, 1965). Recently Daniel, Bloom, Giddings, Campbell, and Turnbull (1968) showed that there is an increased risk of thrombosis when lactation is suppressed by oestrogen which supports the view that oestrogen may be the harmful component of the progestogen-oestrogen combination.

A group of women volunteers was started on chlormadinone acetate; about half had not previously taken pill preparations, and the others were already taking them. The results are seen in Figure 4.

In this trial, in addition to clotting studies, platelet aggregation, fibrinolytic (dilute clot lysis), and thrombelastographic assays were included. The pattern of clotting response in the two groups is also seen in Figure 4.

The women in the group not already having taken oral contraceptives provided no statistically significant change in any of the clotting tests or specific coagulation assays over the first three cycles. The dilute whole blood clot lysis time was
- Factor X

o Factor VII

Fig. 4 Factor VII and $X$ assays during three months of chlormadinone administration. 'Pill' group expressed as percentage of mean control times. Chlormadinone acetate group not having taken oral contraceptives previously. - - - Group who had changed to chlormadinone acetate from other 'pill' preparations.

modified by using a $1 / 20$ dilution. From the second month onwards a significant shortening of the clot lysis time was noted. In the patients followed by thrombelastography no alteration in the thrombelastographic pattern was observed. Platelet aggregation studies showed no significant change with either coagulation-induced (Chandler's tube) or adenosine-diphosphateinduced (ADP) methods.

The second group of women had been taking some conventional oestrogen-progestogen combinations for an average of 14 months. There was a significant shortening of the prothrombin time and significantly raised levels of factor VII and factor $\mathrm{X}$ before they began taking chlormadinone. Cephalin times were not shortened. The results of factor VII and X assays over the three months of chlormadinone administration are shown in Figure 4. By the second month the prothrombin time had returned to the normal range and by the third month the factor VII level was no longer significantly high. By six months the factor $\mathrm{X}$ level had fallen to normal (unpublished data).

A number of further studies confirm the view that platelet surface clotting systems have a key role in haemostasis (Hellem and Owren, 1964). Platelet aggregation is reduced by coumarin anticoagulants (Poller et al, 1969a and b) and is increased after physical exertion when the levels of 'intrinsic' clotting factors rise. It seemed likely 
that platelet aggregation might be increased during oral contraception when the clotting factors rise. We studied the adenosine-diphosphate phase and the thrombin phase using the optical density and Cbandler's tube methods respectively. The optical density method measures the increased transmission of light when a suspension of platelets is aggregated, and the Chandler's tube method the platelet 'snowstorm' which occurs before plasma clots. There are good grounds for believing that the latter may be more physiological and less artificial a method. It measures the coagulation-induced final phase of platelet aggregation which is irreversible. The ADP phase is the stage of reversible platelet aggregation.

Women using oral contraception were compared with normal controls and a group in the third trimester of pregnancy. Results are given in Table $\mathrm{X}$ and Figure 5.

\begin{tabular}{llll}
\hline Group & $\begin{array}{l}\text { No. in } \\
\text { Group }\end{array}$ & $\begin{array}{l}\text { Mean Aggregation } \\
\text { Time }(\text { min) }\end{array}$ & $S D$ \\
\hline Normal controls & 63 & 6.0 & 1.08 \\
'High dose' combined & 14 & 5.2 & 1.34 \\
'Low dose' combined & 32 & 5.1 & 0.73 \\
Progestogen $(a)$ & & & \\
Before starting & 32 & 6.1 & 1.38 \\
After 1 month & 21 & 5.6 & 1.23 \\
After 3 months & 20 & 5.8 & 1.51 \\
After 6 months & 17 & 6.2 & 1.30 \\
Progestogen (b) & & & \\
Base Line & 15 & 5.3 & 0.72 \\
After 1 cycle & 13 & 5.9 & 1.62 \\
After 3 cycles & 12 & 5.7 & 1.05 \\
After 6 cycles & 8 & 5.8 & 0.68 \\
Normal pregnancy & 26 & 4.4 & 1.26 \\
\hline
\end{tabular}

Table X Results of Chandler's tube platelet aggregation

No significant changes were found in the ADP phase. Platelet aggregation was significantly accelerated with the coagulation-induced Chandler's tube technique in women taking combined oestrogen-progestin oral contraceptives, although this was less than in the third trimester of pregnancy (Table X). Women taking the pure progestogen, chlormadinone acetate, did not show this change up to the sixth month of study. In contrast the accelerated platelet aggregation resulting from conventional oral contraception became normal one month after the woman changed to progestogen.

\section{Discussion}

What conclusions may therefore be drawn from these studies? First, conventional oestrogen/ progestogen preparations produce raised levels of certain clotting factors and increased platelet aggregation in the thrombin phase, probably via the same clotting mechanism. Although these changes do not involve as broad a spectrum of

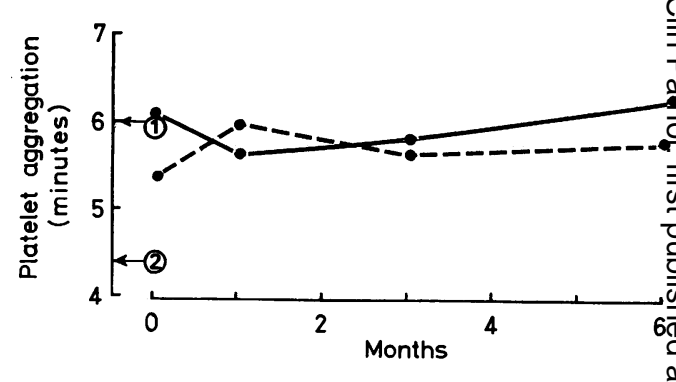

Fig. 5 Platelet aggregation after progestogen administration by Chandler's tube 1 Normal females

2 Third trimester of pregnancy

Progestogen Groups:

$\bigcirc-\bigcirc$ Not previously on other preparations

$\bigcirc----\bigcirc$ Previously on other preparations

clotting factors as thrombosis and the thinf trimester of pregnancy, they do not appear desirable side effect and may be responsible fơ the increased risk of thrombosis.

Oral contraception with progestogen alons does not appear to cause similar clotting an $\$$ platelet changes. To exemplify these differences thrombelastographic patterns are shown i Figure 6. The thrombelastograph measures the speed of coagulation and the resistance of the resultant clot. Hypercoagulable patterns are clearly recognized and patterns are recordes photographically. The first, $A$, is a norma pattern; $\mathrm{B}$, is a typical hypercoagulability patter we obtained in a woman on combined oral copf traception; $\mathrm{C}$ is the classical extreme hyper: coagulability ('cognac glass') pattern seen in $\frac{8}{0}$ patient with deep vein thrombosis following ora contraception. The first pattern is of interest. because it is typical of the normal pattern obtained from women using the progestogen oral contraceptive.

In coagulation studies in women taking pit preparations, most investigators have used onl screening methods and not specific clotting factoro assays. Thus many reports (eg, Ygge, Brody, Korsan-Bengtsen, and Nilsson, 1969) have bee published of shortened ' $p$ and $p$ ' tests measuring the combined factor II, factor VII, and factor levels. An appreciable number of investigators have, however, been unable to confirm these findings (Banks, Rutherford, Coburn, and Welsh? 1966). In most instances only small numbers of women were followed, with the emphasis oP the first one or two cycles where we have show及 that the changes are not yet significant.

The importance of adequate control groups is of course paramount. Positive as well as negative controls are necessary to be certain that the assa 8 system is sufficiently sensitive to record raise levels of clotting factors. Thus we have alwas 


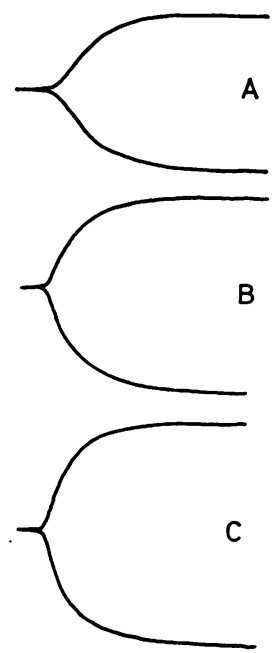

Fig. 6 Thrombelastographic patterns:

A A normal pattern after three months on chlormadinone acetate.

B Hypercoagulability after 12 months on a conventional oestrogen-progestogen compound.

C Extreme hypercoagulability pattern of a patient suffering from a deep-vein thrombosis after oral contraceptive administration.

included at least one control in whom factor VII is known to be raised, eg, women with recent thrombosis and in the third trimester of pregnancy, in each of our investigations. Parallel control observations are essential to standardize the variables in clotting factor assays over months or years.

In addition to changes in clotting factors VII and $X$, there have been reports of raised fibrinogen levels after oral contraception (Brakman and Astrup, 1963). We also have found this to be the case in women on long-term combined preparations.

Although changes in factor VIII levels were reported (Egeberg and Owren, 1963), these had not been confirmed by ourselves or other workers. We have, however, shown that our technique picks out physiological rises in levels of factor VIII after physical exertion. If there is a rise in factor VIII, it is not as great as the physiological changes following exercise. Egeberg (1969) has shown that oral contraceptives given to patients with haemophilia produce a marked shortening of the cephalin time but no change in factor VIII levels.

The findings from fibrinolytic studies have been conflicting. Brackman and Astrup (1963) and
Fearnley (1965) reported increased fibrinolytic activity and raised fibrinogen levels in women using combined preparations. The results obtained with dilute blood clot lysis times by Fearnley were inconclusive. We have found shortened dilute blood clot lysis times in some women on chlormadinone acetate, although the pattern with oral contraceptives has not been constant. There appears also a trend towards shortened euglobulin lysis times with combined preparations in our unpublished data.

Our study on platelet aggregation showed that combined oral contraceptives accelerated the final thrombin phase of platelet aggregation. The progestogen had no such effect and therefore the changes are thought to be due to the oestrogen component of oestrogen-progestogen combination. Oestrogen has been shown to shorten bleeding times and correct abnormal platelet adhesiveness in Von Willebrand's disease (Winckelmann and Köhler, 1964). Beneficial effects in other disorders of platelet adhesiveness are described by Ulutin (1969). Poliwoda (1961) noted that oestriol injections caused an increase in platelet factor IIIlike activity. We did not find any change in the ADP phase of platelet aggregation with oral contraceptives using the optical density method. Bolton, Hampton, and Mitchell (1968), using the electrophoretic technique, found abnormal mobility in response to ADP in women taking combined preparations similar to the pattern in patients with ischaemic heart disease. This effect was absent with the progestogen, chlormadinone acetate.

The important question therefore is whether abnormal increases in two or three clotting factors or mechanisms can be regarded as unequivocal evidence of hypercoagulability. It is difficult to be dogmatic on this point without showing that some overall measure of coagulability is also accelerated. An increase in some clotting factors might be balanced by a reduction in others. Conventional clotting time studies are too coarse or too specific to be regarded as adequate. Heparin clotting times are also likely to be specifically affected by antiheparins. This procedure was therefore discontinued after our first study. We have used the thrombelastograph instead recently, as it is perhaps the best measure available although probably insensitive to the extrinsic system. For the intrinsic system we have used the cephalin times as an overall test, and for the extrinsic system the prothrombin time coupled with the specific factor VII and X assays.

The association of the abnormal thrombelastograph pattern after conventional combined preparations, together with studies of coagulation and platelet changes, appears strong evidence that an abnormal state of coagulability, to which the term 'hypercoagulability' might reasonably be applied, occurs during periods of conventional combined oral contraception. This state is absent in women taking oestrogen-free oral contra- 
ceptives with the progestogen, chlormadinone acetate.

\section{References}

Banks, A. L., Rutherford, R. N., Coburn, W. A., and Welsh, Robert L. (1966). The relationship of clotting factors to dosage levels of estrogen and progestogen-like combinations. Int. J. Fertil., 11, 277-280.

Berkarda, B., Akokan, G., and Derman, U. (1965). The effect of oestriolsuccinate on blood coagulation. J. Atheroscler Res., 5, 595-599.

Blackburn, E. K. (1963). Long-term treatment of epistaxis with oestrogens. Brit. med. J., 2, 159-160.

Bolton, C. H., Hampton, J. R., and Mitchell, J. R. A. (1968). The effect of oral contraceptive agents on platelets and plasma phospholipids. Lancet, 1, 1336-1341.

Brakman, P., and Astrup, T. (1963). Selective inhibition in human pregnancy blood of urokinase induced fibrinolysis. Scand. J. clin. Lab. Invest., 15, 603-609.

Daniel, D. G., Bloom, A. L., Giddings, J. C., Campbell, H., and Turnbull, A. C. (1968). Increased factor IX levels in puerperium during administration of diethylstilboestrol. Brit. med. J., 1, 801-803.

Egeberg, O. (1969). In Fifth Congress of the Asian and Pacific Society of Haematology, Abstract Book, p. 147.

Egeberg, O., and Owren, P. A. (1963). Oral contraception and blood coagulability. Brit. med. J., 1, 220-221.

Fearnley, G. R. (1965). Fibrinolysis, p. 166. Arnold, London.

Hellem, A., and Owren, P. A. (1964). The mechanism of the hemostatic function of blood platelets. Acta haemat. (Basel), 31, 230-238.

Hougie, C., Rutherford, R. N., Banks, A. L., and Coburn, W. A. (1965). Effect of a progestin estrogen oral contraceptive on blood clotting factors. Metabolism, 14, 411-417.

Inman, W. H. W., and Vessey, M. P. (1968). Investigation of deaths from pulmonary, coronary and cerebral thrombosis and embolism in women of child-bearing age. Brit. med.J., 2, 193-199.

Jeffcoate, T. N. A., Miller, J., Roos, R. F., and Tindall, V. R. (1968). Puerperal thromboembolism in relation to the inhibition of lactation by oestrogen therapy. Brit. med. J., 4, 19-25.

Jordan, W. M. (1961). Pulmonary embolism. Lancet, 2, 1146-1147

Medical Research Council Subcommittee (1967). Risk of thrombobolic disease, in women taking oral contraceptives. Brit. med. J., 2, 355-359.
Poliwoda, H. (1961). Treatment of thrombocytopaenic haemor rhage with oestriol succinate. Nature (Lond.), 191, 400.

Poller, L. (1957). Thrombosis and factor VII activity. J. clin. Path., 10, 348-350.

Poller, L., Priest, C. M., and Thomson, J. M. (1969a) Platelet aggregation during oral contraception. Brit. med? J., 4, 273-274.

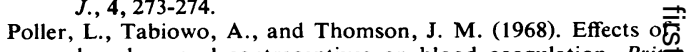
low-dose oral contraceptives on blood coagulation. Brif. med. J., 3, 218-219.

Poller, L., and Thomson, J. M. (1966). Clotting factors durin है oral contraception: further report. Brit. med.J., 2, 23-25

Poller, L., and Thomson, J. M. (1969). Sequential oral con traception and clotting factors. Brit. med. J., 2, 822-823. D

Poller, L., Thomson, J. M., Tabiowo, A., and Priest, C. M (1969b). Progesterone oral contraception and blooछे coagulation. Brit. med. J., 1, 554-556.

Rizza, C. R. (1961). Effect of exercise on the level of antihaemo $\overrightarrow{0}$ philic globulin in human blood. J. Physiol. (Lond.), 156, 128-135.

Thomson, J. M., and Poller, L. (1965). Oral contraceptive hormones and blood coagulability. Brit. med. J., 2, 270-273

Ulutin, O. N. (1969). Sex hormones in blood coagulation. F Recent Advances in Blood Coagulation, p. 220, edited by Lis Poller. Churchill, London.

Vessey, M. P., and Doll, R. (1968). Investigation of relatiów between use of oral contraceptives and thromboembolic. disease. Brit. med. J., 2, 199-205.

Winckelmann, G., and Köhler, H. (1964). Die Beeinflussung deN Plättchenadhäsivität beim v. Willebrand-Jurgens-Syndron durch Oestriolsuccinat. Klin. Wschr., 42, 1098-1099.

Ygge, J., Brody, S., Korsan-Bengtsen, K., and Nilsson, L. (1969). Changes in blood coagulation and fibrinolysis in wome receiving oral contraceptives. Amer. J. Obstet. Gynec., 10年 87-58.

Zilkha, K. J. (1964). Cerebro vascular accidents and oral contra ception. Brit. med. J., 2, 1132-1133. 